\title{
EFIKASI DIRI GURU, PEMAHAMAN TENTANG KARAKTER SISWA, DAN PEMAHAMAN TENTANG KETERAMPILAN ABAD KE-21 SEBAGAI PREDIKTOR GAYA MENGAJAR TIPE FASILITATOR
}

\author{
Aditya Wiranata Sa'pang ${ }^{1}$ \& Rijanto Purbojo ${ }^{2}$ \\ ${ }^{1}$ Sekolah Dian Harapan, Jalan Bedugul No. 1, Daan Mogot Baru, Jakarta 11840, Indonesia \\ ${ }^{2}$ Fakultas Psikologi, Universitas Pelita Harapan, Jalan M.H. Thamrin Boulevard 1100, Karawaci 15811, \\ Indonesia \\ Korespondensi: \\ e-mail: wiranata_aditya@ymail.com
}

\begin{abstract}
This study aims to examine the effect of teachers' self-efficacy, their understanding of student characteristics (known as generation Z), and their understanding of the $21^{\text {st }}$ century skills towards facilitator teaching style at Dian Harapan School Jakarta. This study used a quantitative approach with 60 respondents. Data was collected using questionnaire, which comprises the Teachers' Sense of Efficacy Scale, the characteristics of generation Z Students, West Virginia $21^{\text {st }}$ Century Teaching and Learning Survey, and Teaching Style Survey. Data analysis and hypothesis testing were conducted through multiple linear regression analysis and the $F$ Test. The results showed that teachers' self-efficacy, teachers' understanding of the generation $Z$ students' characteristics, and their understanding of the $21^{\text {st }}$ century skills contribute $60.7 \%$ on teachers' facilitator style of teaching. It was concluded that these three factors have an important role on teachers' facilitator

style of teaching.
\end{abstract} Article history:

Received 20 August 2019

Received in revised form 12 February 2020

Accepted 1 March 2020

Available online 10 June 2020

Keywords:

characteristics of generation Z;

facilitator;

self-efficacy;

teaching style;

$21^{\text {st }}$ century skills

\begin{abstract}
Abstrak - Penelitian ini bertujuan untuk mengetahui pengaruh efikasi diri guru, pemahamannya tentang karakter siswa generasi $\mathrm{Z}$, dan pemahamannya tentang keterampilan abad ke-21 terhadap gaya mengajar guru tipe fasilitator di Sekolah Dian Harapan Jakarta. Metode yang digunakan adalah pendekatan kuantitatif dengan jumlah partisipan 60 orang. Data diperoleh melalui kuesioner yang terdiri dari Teachers' Sense of Efficacy Scale, Karakteristik Generasi Z, West Virginia $21^{\text {st }}$ Century Teaching and Learning Survey, dan Teaching Style Survey. Analisis data dan uji hipotesis dilakukan dengan analisis regresi linear berganda dan uji F Simultan. Hasil yang diperoleh adalah sebesar $60.7 \%$ efikasi diri guru, pemahaman guru tentang karakter siswa generasi Z, dan keterampilan abad ke-21 berkontribusi secara simultan terhadap gaya mengajar guru tipe fasilitator. Dengan demikian, ketiga faktor tersebut berperan penting dalam gaya mengajar guru tipe fasilitator.
\end{abstract}

Kata Kunci: efikasi diri; fasilitator; gaya mengajar; karakter generasi Z; keterampilan abad ke-21 


\section{PENDAHULUAN}

Guru adalah ujung tombak dalam dunia pendidikan. Kompetensi seorang guru dalam menjalankan tugas-tugasnya akan membawa dampak besar bagi para siswa yang diajarnya. Pemerintah telah menetapkan empat kompetensi yang harus dikuasai guru, yaitu kompetensi kepribadian, sosial, pedagogi, dan profesional (UU Nomor 14 Tahun 2005 Bab IV Pasal 10). Pengembangan kompetensi guru ini akan membawa dampak bagi praktik pembelajaran yang dilaksanakan guru, terutama dalam hal gaya mengajar.

Ahmadi dan Prasetya (2005) menyatakan bahwa gaya mengajar adalah tingkah laku, sikap, dan perbuatan guru dalam melaksanakan proses pengajaran. Seorang guru dapat dikenali melalui gaya mengajarnya dan cara memimpinnya di kelas. Hal ini akan berdampak pada para siswa dan proses belajar mereka (Grasha, 2002). Setiap guru memiliki gaya mengajar masing-masing, tetapi memiliki tujuan yang sama, yaitu meningkatkan minat belajar siswa dan kemandirian dalam belajar (Saswandi, 2014). Gaya mengajar diekspresikan dalam cara guru menyampaikan materi, berinteraksi dengan siswa, merancang aktivitas pembelajaran, dan mengelola perilaku siswa.

Grasha (2002) menyatakan bahwa terdapat lima jenis gaya mengajar. Pertama, expert adalah gaya mengajar yang menekankan pada penguasaan konten yang sangat baik oleh guru dan guru dipandang sebagai gudang ilmu. Kedua, formal authority adalah gaya mengajar yang menekankan pada posisi guru sebagai otoritas tertinggi dalam aktivitas pembelajaran, di mana guru menetapkan aturan, prosedur, dan ekspektasi dalam pembelajaran. Ketiga, personal model adalah gaya mengajar yang menekankan pada guru sebagai contoh bagi siswa dalam belajar, di mana guru menjadi patron bagi siswa dalam memperoleh suatu pengetahuan. Dengan kata lain, guru menjadi sosok teladan bagi siswa dan cara terbaik bagi siswa untuk belajar menirukan apa yang disampaikan oleh sang guru. Keempat, facilitator adalah gaya mengajar yang menekankan pada peran guru sebagai fasilitator dalam pembelajaran. Ciri utama gaya mengajar ini terletak pada komunikasi aktif guru dan siswa, di mana guru memberikan stimulus berupa pertanyaan atau arahan kepada siswa agar mereka dapat mengkonstruksi pemahaman mereka. Siswa juga didorong untuk menjadi pembelajar yang aktif. Kelima, delegator adalah gaya mengajar yang menekankan pada penugasan dan kemandirian siswa dalam belajar. Guru banyak memberikan proyek kerja, baik secara individu maupun kelompok untuk melatih kemandirian siswa dalam belajar. Tiga gaya mengajar pertama, yaitu expert, formal authority, dan personal model dikelompokkan ke dalam gaya mengajar yang 
berpusat pada guru. Sementara itu, gaya mengajar facilitator dan delegator dipandang sebagai gaya mengajar yang berpusat pada siswa.

Rahmawati dan Suryadi (2019) menyatakan bahwa kurikulum 2013 saat ini menitikberatkan pada keaktifan siswa dalam belajar, di mana siswa belajar dari pengalaman dan pemikiran kritis, sehingga gaya mengajar guru yang ditekankan adalah gaya fasilitator. Pada penelitiannya, ditemukan bahwa guru yang berperan sebagai fasilitator dalam pembelajaran berpengaruh positif terhadap peningkatan efektivitas belajar siswa. Guru dengan gaya mengajar fasilitator memiliki kemampuan interpersonal yang baik, di mana mereka mampu menjalin komunikasi yang baik dengan siswa, memotivasi dan membangkitkan minat siswa dalam belajar, memahami kebutuhan siswanya, dan secara kooperatif membimbing siswa dalam menghadapi tantangan pada proses pembelajaran (Baleghizadeh \& Shakouri, 2017). Seperti yang telah dikemukakan sebelumnya, gaya mengajar fasilitator menekankan pada komunikasi aktif guru dan siswa. Melalui komunikasi tersebut, guru mengajukan pertanyaan-pertanyaan yang membangkitkan minat dan rasa ingin tahu siswa, serta mendorong siswa membangun pengetahuan mereka dengan menggunakan berbagai macam sumber belajar (Sural, 2019). Dengan demikian, gaya mengajar fasilitator ini tidak menjadikan guru sebagai sumber belajar yang paling utama. Guru membimbing dan mendorong siswa untuk bereksplorasi secara aktif, mandiri, dan bertanggung jawab.

Mulayasa (2013) menyatakan bahwa guru dengan gaya mengajar fasilitator harus memiliki pemahaman yang baik terhadap siswa melalui kegiatan pembelajaran dan mampu menyikapi perbedaan setiap individu dengan baik. Hal ini merupakan salah satu tugas dan tantangan bagi guru. Guru harus memiliki kemampuan dalam mengidentifikasi karakteristik siswanya, seperti cara belajar, bersosialisasi, berkomunikasi, dan minat mereka. Tantangan lainnya adalah kemampuan mengelola pembelajaran agar relevan dengan kehidupan siswa. Tantangan-tantangan ini harus mampu dijawab oleh guru dalam rangka menyiapkan peserta didik menghadapi masa depan mereka. Kesanggupan guru dalam menjawab tantangan dalam tugas pekerjaannya ini berkaitan erat dengan efikasi diri guru, yaitu keyakinan seseorang pada kapasitas dirinya. Dengan demikian, gaya mengajar fasilitator menuntut keyakinan guru pada kemampuannya untuk dapat mengerjakan tugastugasnya yang penuh dengan tantangan, baik itu terkait dengan karakter siswa maupun terkait tuntutan kurikulum.

Pada masa kini, siswa yang duduk di bangku sekolah menengah dapat digolongkan sebagai generasi Z. Generasi ini sering disebut sebagai digital natives, yaitu generasi yang erat dengan teknologi dalam kegiatan mereka sehari-hari. Sementara itu, para guru pada umumnya berasal dari 
generasi terdahulu, yaitu generasi X (lahir di antara tahun 1961-1980) dan Y (lahir di antara tahun 1981-1995). Pengelompokkan generasi ini dilakukan oleh para peneliti sejak tahun 1990-an untuk kepentingan berbagai penelitian, khususnya yang mengangkat masalah kesenjangan atau gap antar generasi (Bencsik, Csikos, \& Juhez, 2016).

Generasi $\mathrm{X}$ tumbuh besar dalam kondisi sosio-historis pasca perang dunia ke-2, krisis energi, dan perang dingin. Mereka kemudian tumbuh menjadi orang-orang yang tangguh, mandiri, loyal, disiplin, dan pekerja keras. Generasi Y lahir dan tumbuh di masa awal perkembangan teknologi. Mereka memiliki keinginan berprestasi yang tinggi, percaya diri, dan optimis (Bala, 2018). Di lain sisi, generasi $\mathrm{Z}$ adalah generasi yang tumbuh dan berkembang dengan sebuah ketergantungan besar pada teknologi digital (Pratama, 2012). Ketergantungan itu merambah ke beberapa aspek kehidupan mereka. Carter (2018) menyatakan bahwa siswa generasi Z memanfaatkan teknologi sebagai media belajar, terutama fasilitas internet yang memungkinkan mereka menemukan berbagai informasi. Selain itu, mereka juga memanfaatkan teknologi untuk terhubung dengan jejaring sosial mereka. Mereka mengandalkan grafik visual pada perangkat elektronik mereka untuk berkomunikasi. Oleh karena itu, gaya hidup siswa yang erat dengan teknologi dapat dimanfaatkan oleh guru untuk menunjang pembelajaran mereka. Guru memfasilitasi siswa dengan media pembelajaran yang berbasis teknologi, sehingga siswa dapat bereksplorasi secara mandiri dengan menggunakan berbagai sumber belajar yang ada dan tidak lagi hanya mengandalkan guru untuk mendapatkan pengetahuan.

Pesatnya perkembangan ilmu pengetahuan dan teknologi yang melahirkan generasi $\mathrm{Z}$ juga turut mengubah arah tuntutan kurikulum. Saat ini, praktik pembelajaran di sekolah menuntut guru untuk mengembangkan keterampilan yang dibutuhkan siswa dalam menjawab tantangan zaman. Keterampilan ini dikenal dengan istilah keterampilan abad ke-21 yang terdiri dari keterampilan berpikir kritis dan pemecahan masalah, kreativitas dan inovasi, keterampilan berkolaborasi, dan keterampilan berkomunikasi (Kereluik, Mishra, Fahnoe, \& Terry, 2013). Untuk membantu siswa mengembangkan keterampilan-keterampilan tersebut, maka guru perlu menerapkan gaya mengajar yang mendorong siswa untuk berperan aktif dan kreatif dalam kegiatan pembelajaran. Oleh karena itu, dibutuhkan guru yang tidak hanya menguasai konten, melainkan juga menguasai pedagogi dan teknologi dalam memfasilitasi pengalaman belajar siswa (Mishra \& Mehta, 2016).

Berdasarkan penjelasan di atas, gaya mengajar tipe fasilitator mengharuskan guru memiliki keyakinan pada kemampuan atau kompetensinya dalam menjawab berbagai tantangan di masa kini. Tantangan tersebut berkaitan erat dengan perbedaan karakteristik siswa yang digolongkan ke daam 
generasi Z, yaitu generasi yang hidup erat dengan teknologi dan tuntutan kurikulum yang menekankan pada pengembangan keterampilan abad ke-21. Oleh karena itu, dengan efikasi diri yang tinggi, pemahaman yang baik tentang karakter siswa generasi $\mathrm{Z}$, dan pemahaman yang baik tentang keterampilan abad ke-21, maka guru dapat mengoptimalkan gaya mengajar tipe fasilitator untuk diterapkan dalam pembelajaran di kelas.

\section{Efikasi Diri Guru}

Bandura (1997) mendefinisikan efikasi diri sebagai kepercayaan seseorang pada kemampuan dirinya dalam mengelola dan mengatur berbagai tindakan yang diperlukan untuk menghadapi berbagai situasi. Bosscher dan Smit (1998) menyatakan bahwa efikasi diri adalah keyakinan seseorang terhadap kemampuannya dalam mengatur perilaku tertentu dan melaksanakannya untuk mencapai hasil yang diinginkan. Sementara itu, Alwisol (2018) menyatakan bahwa efikasi diri merupakan penilaian seseorang terhadap dirinya sendiri dalam mengeksekusi suatu tugas dan kesanggupan mencapai hasil terbaik.

Efikasi diri bersumber dari empat hal, yaitu pengalaman di masa lalu, pengalaman orang lain, persuasi verbal, serta kondisi fisiologi dan afeksi (Bandura, 1997). Pengalaman diyakini sebagai sumber utama yang paling besar dampaknya bagi efikasi diri seseorang. Hal ini berlaku pula bagi seorang guru. Setiap guru pasti memiliki latar belakang pendidikan dan pengalaman mengajar, di mana hal ini menjadi sumber efikasi diri bagi guru dalam menghadapi tugas-tugasnya. Pengalaman mengajar di masa lalu, menangani masalah siswa, dan mengelola kelas menjadi modal utama yang membangkitkan rasa percaya diri guru dalam menjalankan tugas-tugasnya di kemudian hari.

Bandura (1997) menjelaskan bahwa salah satu tugas guru adalah menciptakan lingkungan belajar yang kondusif demi perkembangan kognitif siswa. Guru yang memiliki efikasi diri dalam pembelajaran akan bekerja berdasarkan keyakinan bahwa semua siswa dapat mengikuti dan mencapai tujuan pembelajaran apabila diikuti oleh usaha keras dari guru dalam mengelola pembelajaran. Dengan demikian, dapat disimpulkan bahwa efikasi diri guru merupakan keyakinan diri guru pada kemampuannya untuk menghadapi tugas-tugasnya, baik tugas yang berhubungan dengan konten pelajaran dan cara penyampaiannya maupun berinteraksi dan mengelola perilaku siswa di kelas. Efikasi diri seseorang dapat diukur berdasarkan tiga dimensi, yaitu tingkat kesulitan, generalitas, dan tingkat kekuatan (Bandura, 1997). Dimensi tingkat kesulitan merujuk pada tingkat kesulitan tugas yang diyakini dapat diatasi. Tingkat efikasi diri seseorang bergantung pada tingkat 
kesulitan tugas yang dihadapi. Dimensi generalitas merujuk pada keyakinan seseorang dalam menghadapi situasi yang lebih bervariasi. Sementara itu, dimensi tingkat kekuatan merujuk pada seberapa kuat keyakinan seseorang atas kemampuannya. Untuk mengukur efikasi diri pada guru, Bandura menggunakan pendekatan pada tugas-tugas harian guru, di antaranya membuat keputusan, memilih strategi pembelajaran, dan melatih kedisiplinan siswa. Kemudian, Tschannen-Moran dan Hoy (2001) mengembangkan instrumen untuk mengukur efikasi diri pada guru melalui tiga dimensi utama, yaitu efikasi diri dalam strategi pembelajaran, berinteraksi dengan siswa, dan manajemen kelas.

\section{Pemahaman Guru tentang Karakter Siswa Generasi Z}

Menurut Bencsik, Csikos, dan Juhez (2016), generasi Z adalah suatu generasi yang lahir antara tahun 1995-2010. Chun dkk. (2017) menyatakan bahwa generasi Z disebut pula sebagai digital natives karena mereka lahir di masa penggunaan internet yang semakin dikenal luas. Mereka telah mengenal berbagai macam perangkat teknologi informasi dan komunikasi berbasis internet. Menurut Suganda (2018), generasi Z merupakan generasi yang suka bersosialisasi dan mengekspresikan diri, aktif dalam berbagai kegiatan, berpikir global, berkomunikasi secara digital, dan menyukai hal-hal visual. Sementara itu, Carter (2018) menyoroti gaya komunikasi generasi Z yang gemar terhubung melalui perangkat elektronik dan akses internet menjadi sarana utama dalam berkomunikasi. Gaya komunikasi mereka adalah komunikasi non-verbal dengan mengandalkan grafik-grafik visual pada perangkat elektronik.

Saat ini, generasi $\mathrm{Z}$ adalah mereka yang duduk di bangku sekolah dasar sampai SMA. Ramar dan Sharma (2016) mengidentifikasi beberapa karakteristik siswa generasi Z, di antaranya menyukai metode pembelajaran secara visual, suka dilibatkan pada berbagai aktivitas, mengharapakan penghargaan atas usaha mereka, dan memiliki waktu fokus yang singkat. Sementara itu, Nai (2017) menyatakan bahwa siswa generasi Z membutuhkan atmosfer pembelajaran digital secara kolaboratif, serta menemukan dan memecahkan masalah secara bersama-sama. Lebih lanjut, Schwieger dan Ludwig (2018) berpendapat bahwa siswa generasi Z memiliki kreativitas dan jiwa wirausaha yang tinggi, memiliki ambisi yang besar, serta dapat mempelajari hal yang mereka sukai secara mandiri. Selain diberikan konten atau materi, siswa generasi $\mathrm{Z}$ juga harus diberikan relevansi dari materi tersebut dalam kehidupan mereka. Mereka juga perlu diberi wadah untuk menuangkan kreativitas mereka melalui media atau teknologi secara bertanggung jawab. Guru tidak dapat menahan siswa dari berinteraksi dengan teknologi, melainkan 
guru perlu memanfaatkan kedekatan siswa dengan teknologi tersebut untuk menunjang pembelajaran mereka.

\section{Pemahaman Guru tentang Keterampilan Abad ke-21}

Perkembangan ilmu pengetahuan dan teknologi mendorong peningkatan mutu dan kualitas pendidikan. Sekolah harus mampu mempersiapkan para siswa untuk terjun ke masyarakat dan memberikan kontribusi positif. Oleh karena itu, praktik pendidikan harus berubah mengikuti perkembangan dan tren di abad ke-21 ini. Kereluik dkk. (2013) menyatakan bahwa terdapat tiga ranah utama dalam pembelajaran abad ke-21, yaitu, pengetahuan dasar, pengetahuan humanistik, dan meta-pengetahuan. Ranah terakhir, yaitu meta-pengetahuan merujuk pada bagaimana siswa dapat mengambil tindakan dari pengetahuan dasar yang telah diperoleh. Dengan kata lain, apa yang dapat siswa lakukan dan kerjakan setelah mereka mendapatkan pemahaman dasar atas suatu konsep yang mereka pelajari. Meta-pengetahuan dikenal dengan istilah keterampilan abad ke-21, yaitu keterampilan-keterampilan yang dirasa penting untuk dikuasai pada konteks era digital sekarang ini.

Keterampilan abad ke-21 mencakup keterampilan berpikir kritis dan memecahkan masalah, kreativitas dan inovasi, keterampilan berkomunikasi, dan keterampilan berkolaborasi. Ravitz (2014) mendeskripsikan konsep dasar dari setiap keterampilan tersebut dan menjabarkan hal-hal praktis yang dapat dilakukan oleh guru untuk membantu siswa mengembangkan keterampilanketerampilan tersebut. Hal ini memudahkan guru dalam merancang kegiatan pembelajaran yang dapat menunjang pengembangan keterampilan abad ke-21 pada siswa. Dengan demikian, pembelajaran di kelas tidak lagi hanya sekadar berfokus pada penguasaan konten, melainkan melalui setiap mata pelajaran siswa mengembangkan keterampilan-keterampilan abad ke-21 tersebut (Mishra \& Mehta, 2016).

\section{Kerangka Berpikir}

Peran guru sebagai fasilitator dalam kegiatan pembelajaran bergantung penuh pada kapasistas diri atau kompetensi yang dimiliki oleh guru. Guru harus memiliki keyakinan akan kemampuan dirinya bahwa dia mampu menjalankan peran seorang fasilitator dalam pembelajaran. Perbedaan generasi antara guru dan siswa, di mana siswa merupakan generasi digital natives dapat menjadi tantangan bagi guru. Kedekatan siswa generasi Z dengan teknologi harus dapat dijadikan kesempatan bagi guru untuk mengintegrasikan teknologi dalam pembelajaran.

Menjadi guru fasilitator tentu harus mampu mengidentifikasi karakteristik para siswa, khususnya dalam hal cara mereka belajar. Guru harus mampu menyediakan lingkungan belajar 
yang sesuai dengan kebutuhan siswa, di mana saat ini para siswa merupakan generasi $Z$ yang sangat erat dengan teknologi. Guru juga perlu memahami tantangan zaman yang menuntut penguasaan keterampilan-keterampilan tertentu yang dibutuhkan siswa di masa depan. Oleh karena itu, proses pembelajaran tidak hanya berfokus pada penguasaan konten, melainkan juga pengembangan keterampilan-keterampilan yang dikenal dengan istilah keterampilan abad ke-21. Dengan demikian, dapat disimpulkan bahwa keyakinan guru pada kapasitas dirinya dalam menjalankan tugnya, bagaimana guru memahami karakter siswa yang merupakan generasi Z, serta bagaimana guru memahami pembelajaran yang berbasis keterampilan abad ke-21 akan memberi pengaruh pada gaya mengajar yang diterapkannya, yaitu fasilitator.

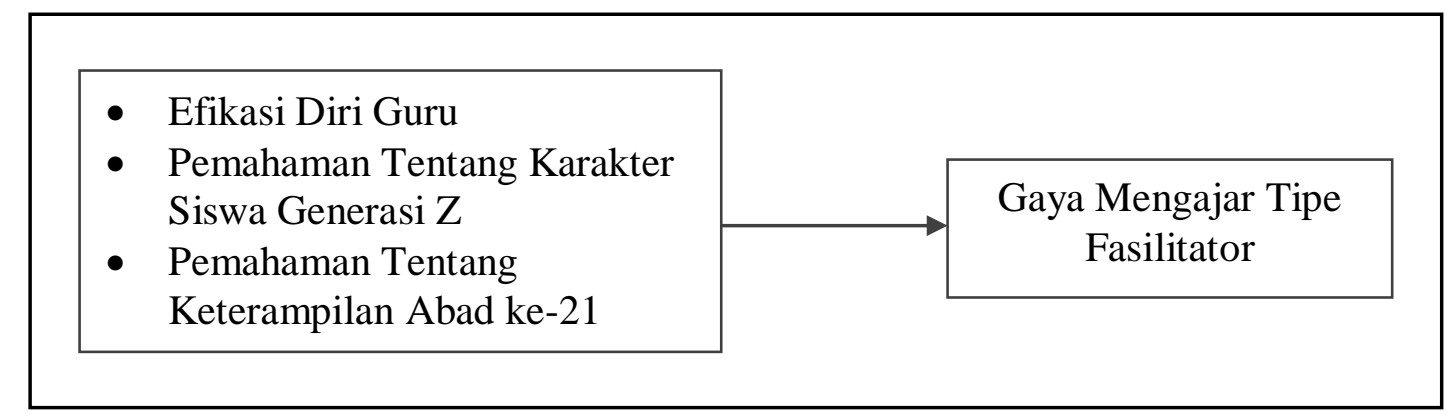

Figur 1. Kerangka Berpikir

Penelitian ini bertujuan untuk mengetahui apakah terdapat pengaruh pada efikasi diri guru, pemahaman guru tentang karakter siswa generasi Z, dan pemahaman guru tentang keterampilan abad ke-21 terhadap gaya mengajar guru tipe fasilitator di Sekolah Dian Harapan Jakarta. Adapun, rumusan hipotesis dalam penelitian ini adalah terdapat pengaruh secara simultan pada efikasi diri guru, pemahaman guru tentang karakter siswa generasi Z, dan pemahaman guru tentang keterampilan abad ke-21 terhadap gaya mengajar guru tipe fasilitator.

\section{METODE}

\section{Partisipan}

Subjek pada penelitian ini adalah guru-guru di Sekolah Dian Harapan Jakarta. Pimpinan sekolah menaruh perhatian pada pengembangan kompetensi guru, khususnya dalam hal pedagogi dan profesional. Oleh karena itu, para guru banyak dibekali dengan professional development (pengembangan profesional) yang sesuai dengan kebutuhan guru dan siswa, serta perkembangan kurikulum. Sekolah ini menerapkan kurikulum 2013 yang diperkaya dengan pengembangan secara internal berdasarkan visi-misi yayasan yang menaungi sekolah. Saat ini, di departemen senior (SMP 
dan SMA) sedang dirintis sistem flipped classroom. Menurut Nouri (2016), flipped classroom adalah sistem pembelajaran yang dapat menjawab kejenuhan dari pembelajaran langsung di kelas, di mana siswa diberikan materi pembelajaran berupa video atau literatur yang dapat diakses dari rumah melalui perangkat komunikasi digital, seperti komputer, laptop, atau ponsel. Kemudian, pada pertemuan di kelas siswa terlibat dalam berbagai aktivitas yang dirancang guru untuk menerapkan apa yang telah dipelajari di rumah. Hal ini dirasa dapat meningkatkan kemandirian siswa dan partisipasi aktif siswa dalam pembelajaran.

Sebagai tahap awal penerapan flipped classroom di Sekolah Dian Harapan, pimpinan memilih empat guru untuk menjalankan pilot project (proyek percontohan) yang nanti akan menjadi percontohan bagi guru-guru lain. Keempat guru tersebut adalah guru-guru yang mengajar mata pelajaran ilmu sosial dan dinilai dapat beradaptasi dengan sistem e-learning. Secara bertahap, guruguru yang lain juga akan menerapkan sistem yang sama. Hal ini berarti guru harus siap dengan perubahan yang ada, terutama dalam hal gaya mengajarnya.

Jumlah guru yang ada di departemen senior adalah 73 orang. Namun, pada penelitian ini guru yang terlibat menjadi partisipan sebanyak 60 orang. Berikut adalah data demografi partisipan berdasarkan jenis kelamin, usia, pengalaman mengajar, dan pendidikan terakhir.

Tabel 1.

Data Demografi Partisipan

\begin{tabular}{|c|c|c|}
\hline Kategori & $n$ & $\%$ \\
\hline \multicolumn{3}{|l|}{ Jenis Kelamin } \\
\hline Laki-laki & 28 & 46.7 \\
\hline Perempuan & 32 & 53.3 \\
\hline \multicolumn{3}{|l|}{ Usia (tahun) } \\
\hline$<26$ & 5 & 8.3 \\
\hline $26-30$ & 10 & 16.7 \\
\hline $31-35$ & 6 & 10.0 \\
\hline $36-40$ & 14 & 23.3 \\
\hline $41-45$ & 12 & 20.0 \\
\hline $45-50$ & 6 & 10.0 \\
\hline$>50$ & 7 & 11.7 \\
\hline \multicolumn{3}{|l|}{ Pengalaman Mengajar (tahun) } \\
\hline$>1$ & 1 & 1.7 \\
\hline $1-3$ & 8 & 13.3 \\
\hline $4-6$ & 10 & 16.7 \\
\hline $7-9$ & 5 & 8.3 \\
\hline$>9$ & 36 & 60 \\
\hline \multicolumn{3}{|l|}{ Pendidikan Terakhir } \\
\hline S1 & 47 & 78.3 \\
\hline $\mathrm{S} 2$ & 13 & 21.7 \\
\hline
\end{tabular}




\section{Desain}

Penelitian ini menggunakan pendekatan kuantitatif yang bertujuan melihat apakah terdapat pengaruh sejumlah variabel secara simultan terhadap variabel lainnya. Variabel dalam penelitian ini terbagi menjadi dua, yaitu variabel prediktor yang terdiri dari efikasi diri guru, pemahaman guru tentang karakter siswa generasi Z, dan pemahaman guru tentang keterampilan abad ke-21. Sementara itu, variabel kriteria dalam penelitian ini adalah gaya mengajar guru tipe fasilitator. Desain penelitian yang bertujuan untuk melihat pengaruh akan dianalisis dengan menggunakan analisis regresi linear berganda dan uji hipotesis.

\section{Prosedur}

Prosedur penelitian ini terdiri atas tiga tahap utama. Tahap pertama adalah tahap persiapan. Pada tahap ini, peneliti mengidentifikasi masalah atau fenomena yang terjadi di lapangan. Kemudian, peneliti juga melakukan kajian literatur dari berbagai sumber, baik dari buku maupun jurnal-jurnal penelitian. Selanjutnya, peneliti juga meminta izin dengan menyerahkan surat permohonan untuk melaksanakan penelitian kepada pimpinan di institusi tempat penelitian diadakan. Kemudian, peneliti mulai menyusun instrumen penelitian, yaitu kuesioner.

Tahap kedua adalah tahap pengumpulan data. Pada tahap ini, peneliti menyebarkan kuesioner kepada para partisipan yang diawali dengan mengisi informed consent untuk terlibat dalam penelitian ini. Sebelum menyebarkan kuesioner, peneliti menjelaskan tujuan dari penelitian ini dan manfaat yang diharapkan dapat dirasakan oleh para partisipan di kemudian hari. Peneliti menyampaikan bahwa kejujuran partisipan dalam mengisi kuesioner ini sangat dibutuhkan karena kuesioner bersifat evaluasi diri, yaitu partisipan memberi penilaian kepada diri sendiri. Oleh karena keterbatasan waktu dan sumber daya, peneliti menggunakan metode one-shot experiment, yaitu pengumpulan data yang dilakukan tanpa uji coba instrumen terlebih dahulu.

Tahap ketiga adalah analisis data. Setelah data melalui uji validitas dan reliabilitas, selanjutnya peneliti melakukan analisis data dan uji hipotesis. Oleh karena penelitian ini bertujuan untuk mengetahui ada tidaknya pengaruh, maka peneliti melakukan analisis regresi linear berganda. Pada akhirnya, peneliti akan menarik kesimpulan berdasarkan hasil analisis data dan menyajikan hasilnya dalam bentuk karya tulis. 


\section{Instrumen}

Instrumen yang digunakan adalah kuesioner tertutup yang terdiri dari empat bagian. Untuk variabel efikasi diri guru (variabel $\mathrm{X}_{1}$ ), peneliti menggunakan kuesioner yang dikembangkan oleh Tschannen-Moran dan Hoy (2001), yaitu Teachers' Sense of Efficacy Scale $(\alpha=.94)$. Kuesioner terdiri dari 24 pernyataan berisi tiga dimensi efikasi diri guru dalam menjalankan tugas-tugasnya, yaitu efikasi diri dalam strategi pembelajaran, interaksi dengan siswa, dan manajemen kelas. Partisipan diminta untuk mengukur keyakinan mereka dengan mengisi angka 1 (Sangat Tidak Yakin) sampai 9 (Sangat Yakin) pada pertanyaan, seperti "Seberapa yakin Anda bahwa anda dapat merespon setiap pertanyaan yang sulit dari siswa Anda?" atau "Seberapa yakin Anda bahwa Anda dapat mengimplementasikan berbagai strategi pembelajaran di dalam kelas?"

Untuk variabel pemahaman guru mengenai karakter generasi $\mathrm{Z}$ (variabel $\mathrm{X}_{2}$ ), peneliti menyusun kuesioner evaluasi pemahaman diri berdasarkan penelitian mengenai karakter generasi $\mathrm{Z}$ yang dilakukan oleh Ramar dan Sharma (2016), Nai (2017), serta Schwieger dan Ludwig (2018). Kuesioner terdiri dari 20 butir pernyataan mengenai karakteristik generasi $\mathrm{Z}$ yang terdiri atas gaya belajar dan hubungan sosial. Kuesioner menggunakan skala Likert 1 (Sangat Tidak Setuju) sampai 5 (Sangat Setuju). Partisipan diminta untuk menanggapi pernyataan, seperti "Siswa saya menyukai belajar dengan praktik langsung daripada teori”, "Siswa saya terhubung dengan temannya melalui media sosial", "Siswa saya lebih menyukai komunikasi non-verbal", dan "Siswa saya suka bekerja sama dalam kelompok".

Untuk variabel pemahaman guru mengenai keterampilan abad ke-21 (variabel $\mathrm{X}_{3}$ ), peneliti mengembangkan kuesioner evaluasi pemahaman diri berdasarkan penelitian yang dilakukan oleh Ravitz (2014) serta Mishra dan Mehta (2016). Kuesioner terdiri dari 20 butir pernyataan mengenai konsep dasar keterampilan abad ke-21 yang dipahami guru dan sejauh mana guru telah menerapkan dalam pembelajaran. Skala yang digunakan adalah skala Likert 1 (Sangat Tidak Setuju) sampai 5 (Sangat Setuju). Partisipan diminta menanggapi pernyataan seperti, “Keterampilan berpikir kritis dapat diajarkan melalui semua bidang studi", "Kemampuan berpikir kreatif tidak terbatas pada pelajaran kesenian", "Saya mendorong siswa menggunakan berbagai sumber belajar, selain penjelasan guru”, dan "Saya memberi kesempatan kepada siswa untuk menjawab pertanyaan yang diajukan temannya".

Variabel keempat adalah gaya mengajar guru tipe fasilitator (variabel Y). Peneliti menggunakan kuesioner yang dikembangkan oleh Grasha (2002), yaitu Teaching Style Inventory dengan nilai $\alpha=.9$ (Beyhan, 2018). Skala yang digunakan adalah skala Likert $1-5$ (Sangat Tidak 
Setuju - Sangat Setuju). Pada bagian ini, peneliti hanya akan mengambil sembilan butir pernyataan saja yang menunjukkan indikator gaya mengajar tipe fasilitator, seperti "Saya menggunakan metode pembelajaran yang memfasilitasi perbedaan cara belajar siswa", "Saya menggunakan diskusi kelompok untuk membantu siswa mengembangkan keterampilan berpikirnya", dan "Saya membimbing siswa dengan pertanyaan pemicu (trigger questions)".

\section{Teknik Analisis}

Analisis data diawali dengan uji validitas dan reliabilitas instrumen. Kemudian, dilanjutkan dengan uji asumsi klasik, yaitu uji prasyarat untuk melakukan analisis regresi. Tahap ini terdiri dari empat jenis uji, yaitu uji normalitas, uji multikolinearitas, uji heteroskedastisitas, dan uji linearitas. Tahap ketiga adalah analisis regresi linear berganda dan uji hipotesis dengan menggunakan uji $\mathrm{F}$ Simultan.

\section{ANALISIS DAN HASIL}

\section{Hasil Uji Validitas dan Reliabilitas}

Hasil yang diperoleh untuk uji validitas adalah semua item dinyatakan valid $(r>.258)$. Selanjutnya, dilakukan uji reliabilitas untuk setiap variabel dengan mencari nilai koefisien Cronbach's Alpha. Nilai alpha untuk variabel efikasi diri guru sebesar .91. Untuk variabel pemahaman guru tentang karakter siswa generasi $\mathrm{Z}$ diperoleh nilai alpha sebesar .709. Untuk variabel pemahaman guru tentang keterampilan abad ke-21 diperoleh nilai alpha sebesar .881. Untuk variabel gaya mengajar guru tipe fasilitator diperoleh nilai alpha sebesar .792.

\section{Hasil Uji Asumsi Klasik}

Uji yang pertama adalah uji normalitas. Uji ini dilakukan untuk melihat apakah nilai residual dari model regresi berdistribusi normal atau tidak. Syarat model regresi yang baik adalah nilai residual berdistribusi normal $(p>.05)$. Hasil yang diperoleh menunjukkan nilai residual pada model regresi berdistribusi normal $(p=.200)$.

Uji kedua adalah uji multikolinearitas, dilakukan untuk melihat apakah ada korelasi yang tinggi antara dua variabel prediktor. Model regresi yang baik tidak memuat gejala multikolinearitas (tolerance $>.1$ atau nilai VIF < 10). Hasil yang diperoleh adalah tidak terdapat korelasi antara dua variabel prediktor pada model regresi (tolerance $\mathrm{X}_{1}=.877 ; \mathrm{X}_{2}=.696 ; \mathrm{X}_{3}=.624$ ). 
Uji ketiga adalah uji heteroskedastisitas, dilakukan untuk melihat apakah variabel prediktor berpengaruh signifikan terhadap nilai residual. Model regresi yang baik seharusnya tidak memuat gejala heteroskedastisitas $(p>.05)$. Hasil yang diperoleh adalah tidak terdapat gejala heteroskedastisitas pada model regresi ini $\left(p \mathrm{X}_{1}=.756 ; \mathrm{X}_{2}=.562 ; \mathrm{X}_{3}=.360\right)$.

Uji yang terakhir adalah uji linearitas, yaitu uji yang dilakukan untuk melihat apakah terdapat hubungan yang linear antara setiap variabel prediktor dengan variabel kriteria. Syarat model regresi yang baik adalah terdapat hubungan yang linear antara kedua variabel $(p>.05$ atau $F$ hitung $<F$ tabel $=1.7$ ). Hasil yang diperoleh adalah setiap variabel prediktor memiliki hubungan linear dengan variabel kriteria $\left(p \mathrm{X}_{1}-\mathrm{Y}=.315 ; \mathrm{X}_{2}-\mathrm{Y}=.591 ; \mathrm{X}_{3}-\mathrm{Y}=.266\right)$. Dari uji ini juga diperoleh koefisien korelasi antara setiap variabel prediktor dengan variabel kriteria, yaitu $\mathrm{X}_{1}-\mathrm{Y}=$ .339 (rendah); $\mathrm{X}_{2}-\mathrm{Y}=.657$ (tinggi); $\mathrm{X}_{3}-\mathrm{Y}=.469$ (sedang). Angka ini dapat digunakan untuk melihat nilai sumbangan efektif setiap variabel prediktor terhadap variabel kriteria dalam model regresi. Berdasarkan hasil uji asumsi klasik yang diperoleh, maka dapat disimpulkan bahwa model regresi pada penelitian ini memenuhi syarat untuk dilanjutkan ke tahap analisis regresi linear berganda dan uji hipotesis.

\section{Hasil Analisis Regresi Linear Berganda dan Uji Hipotesis}

Hasil analisis regresi linear berganda dan uji F simultan disajikan dalam tabel berikut.

Tabel 2.

Hasil Analisis Regresi Linear Berganda

\begin{tabular}{ccc}
\hline \multirow{2}{*}{ Model } & \multicolumn{2}{c}{ Unstandardized Coefficients } \\
\cline { 2 - 3 } & $\boldsymbol{\beta}$ & Standard error \\
\hline Konstan & -5.337 & 5.178 \\
$\mathrm{X}_{1}$ & .045 & .024 \\
$\mathrm{X}_{2}$ & .237 & .056 \\
$\mathrm{X}_{3}$ & .182 & .048 \\
\hline
\end{tabular}

Berdasarkan Tabel 3, diperoleh persamaan regresi: $y=-5.337+.045 X_{1}+.237 X_{2}+.182 X_{3}$. Selanjutnya, dari hasil uji F simultan diperoleh nilai F hitung lebih besar dari F tabel (2.76) dan nilai $p$ kurang dari $.05(\mathrm{~F}=28.879, p=.000)$. Dengan demikian dapat disimpulkan terdapat pengaruh efikasi diri guru, pemahaman guru tentang karakter siswa generasi Z, dan keterampilan abad ke-21 secara simultan terhadap gaya mengajar guru tipe fasilitator di Sekolah Dian Harapan Jakarta. Selain itu diperoleh juga nilai $R^{2}$ sebesar .607 yang menunjukkan bahwa besarnya pengaruh ketiga variabel prediktor secara simultan terhadap variabel kriteria adalah $60.7 \%$. 
Untuk mengetahui variabel mana yang memberikan kontribusi terbesar, dapat diketahui dengan menentukan nilai sumbangan efektif (SE). Hasil yang diperoleh adalah sumbangan efektif efikasi diri guru terhadap gaya mengajar sebesar 5.5\%, sumbangan efektif pemahaman guru tentang karakter siswa generasi $\mathrm{Z}$ terhadap gaya mengajar guru sebesar $27.8 \%$, dan sumbangan efektif pemahaman guru tentang keterampilan abad ke-21 terhadap gaya mengajar guru sebesar $27.4 \%$. Dengan demikian, dapat disimpulkan bahwa pada model regresi dalam penelitian ini pemahaman guru terhadap karakter siswa generasi $\mathrm{Z}$ dan keterampilan abad ke-21 sama-sama memiliki pengaruh dominan terhadap gaya mengajar guru tipe fasilitator.

\section{DISKUSI}

Penelitian ini bertujuan untuk mengetahui apakah terdapat pengaruh efikasi diri guru, pemahaman guru tentang karakter siswa generasi Z, dan pemahaman guru tentang keterampilan abad ke-21 terhadap gaya mengajar guru tipe fasilitator di Sekolah Dian Harapan Jakarta dan seberapa besar pengaruh tersebut. Instrumen yang digunakan dalam penelitian ini adalah kuesioner yang bersifat evaluasi diri yang terdiri dari empat bagian.

Berdasarkan hasil analisis regresi linear berganda dan uji $F$ simultan, diperoleh bahwa efikasi diri guru, pemahaman guru tentang karakter siswa generasi Z, dan pemahaman guru tentang keterampilan abad ke-21 secara simultan berpengaruh terhadap gaya mengajar tipe fasilitator pada guru-guru SMP dan SMA Dian Harapan Jakarta. Nilai koefisien determinasi sebesar .607 menunjukkan bahwa gaya mengajar guru dipengaruhi oleh variasi ketiga faktor tersebut sebesar $60.7 \%$, sedangkan $39.3 \%$ sisanya dipengaruhi oleh faktor-faktor lain yang tidak dibahas dalam penelitian ini. Selanjutnya, dengan mengamati nilai sumbangan efektif, maka dapat disimpulkan variabel pemahaman guru tentang karakter siswa generasi $\mathrm{Z}$ dan keterampilan abad ke-21 memberikan kontribusi yang hampir sama dan paling dominan terhadap gaya mengajar, yaitu masing-masing sebesar $27 \%$.

Faktor efikasi diri guru memberikan kontribusi paling kecil terhadap gaya mengajar guru. Demikian pula dengan hasil korelasinya, yaitu efikasi diri berkorelasi rendah terhadap gaya mengajar tipe fasilitator. Hal ini sesuai dengan temuan Baleghizadeh dan Shakouri (2017) yang menyatakan bahwa sekalipun korelasinya rendah efikasi diri tetap dapat diperhitungkan sebagai faktor yang memengaruhi gaya mengajar tipe fasilitator. Gaya mengajar fasilitator menekankan hubungan positif antara guru dan siswa, di mana guru mampu menciptakan atmosfer belajar yang 
lebih fleksibel dan tidak kaku bagi siswa, serta mendorong kemandirian siswa dalam belajar. Hal ini berkaitan langsung dengan dimensi efikasi diri guru, yaitu strategi pembelajaran, interaksi dengan siswa, dan manajemen kelas. Wicoro (2018) menyatakan bahwa efikasi diri dapat memengaruhi motivasi mengajar guru, di mana salah satu aspek di dalamnya adalah pemilihan pendekatan gaya mengajar. Guru dengan efikasi diri yang tinggi akan mampu mengidentifikasi gaya mengajar apa yang perlu diterapkan agar pembelajaran dapat lebih efektif. Pada penelitian ini, faktor efikasi diri saja tidaklah cukup dalam memberikan pengaruh yang lebih besar kepada gaya mengajar tipe fasilitator. Keyakinan guru pada kemampuan dirinya dalam menjalankan tugasnya perlu dilengkapi dengan kompetensi lain. Dalam hal ini, kompetensi yang dimaksud adalah memahami karakter siswa generasi $\mathrm{Z}$ dan pembelajaran berbasis keterampilan abad ke-21.

Pada penelitian ini, ditemukan bahwa pemahaman guru tentang karakter siswa generasi $\mathrm{Z}$ adalah faktor yang memberikan kontribusi paling besar dalam model penelitian ini, yaitu sebesar 27.8\%. Balachandran (2015) menyatakan bahwa salah satu aspek yang memengaruhi gaya mengajar guru adalah karakteristik dari siswa, artinya guru yang mengenali siswanya dapat merancang pembelajaran dengan lebih efektif sesuai dengan kebutuhan siswa. Nai (2017) menyatakan bahwa siswa generasi $\mathrm{Z}$ membutuhkan atmosfer pembelajaran digital secara kolaboratif. Mereka perlu diberikan suatu masalah dan menemukan pemecahannya secara bersamasama. Bentuk pembelajaran seperti ini dapat difasilitasi dengan gaya mengajar tipe fasilitator, di mana guru mendorong siswanya bereksplorasi, aktif, dan mandiri dalam membangun pengetahuannya (Grasha, 2002). Model pembelajaran seperti ini erat kaitannya dengan pembelajaaran abad ke-21 yang menekankan pada penguasaan keterampilan-keterampilan abad ke21. Hal ini berarti guru perlu memahami keterampilan-keterampilan tersebut dan melatih siswa untuk mengembangkannya.

Pada penelitian ini, pemahaman guru tentang keterampilan abad ke-21 menjadi faktor ketiga yang memberikan kontribusi sebesar $27.4 \%$ terhadap gaya mengajar tipe fasilitator. Hal ini sesuai dengan penelitian Jan (2017) yang menyatakan bahwa guru harus mengubah orientasi pembelajaran dari pembelajaran yang berorientasi pada guru menjadi pembelajaran yang berorientasi pada siswa. Guru juga perlu menguasai teknologi, memberikan proyek mandiri kepada siswa, dan meminta siswa berkolaborasi dengan temannya dalam memecahkan suatu masalah. Praktik-praktik ini sesuai dengan karakteristik gaya mengajar tipe fasilitator yang dikemukakan oleh Grasha (2002). Lebih lanjut lagi, Mishra dan Mehta (2016) juga menyatakan bahwa dalam menghadapi pembelajaran abad ke-21 guru harus menguasai konten yang diajarkan, pedagogi, teknologi, serta menjadi 
fasilitator untuk merancang kegiatan pembelajaran yang membuat siswa mengolah informasi menjadi pengetahuan.

Berdasarkan penjabaran di atas, dapat dilihat hubungan dari variabel-variabel yang dibahas pada penelitian ini. Guru di Sekolah Dian Harapan Jakarta perlu menerapkan gaya mengajar tipe fasilitator karena sesuai dengan kebutuhan siswa masa kini dan tuntutan kurikulum. Hal ini tentu menjadi tantangan tersendiri bagi para guru. Oleh karena itu, mereka perlu memiliki efikasi diri yang tinggi dalam menjalankan setiap tugasnya. Efikasi diri perlu dilengkapi dengan kompetensi diri yang harus terus ditingkatkan. Kompetensi tersebut adalah memahami karakterisitik siswa yang tentu berbeda dengan karakter gurunya dan mengenal apa tuntutan kurikulum saat ini. Dengan efikasi diri yang tinggi, pemahaman yang baik tentang karakter siswa, dan pemahaman yang baik tentang keterampilan abad ke-21, para guru dapat menerapkan atau mengadopsi gaya mengajar tipe fasilitator dengan lebih efektif, sehingga pembelajaran yang diterima oleh siswa juga sesuai dengan apa yang mereka butuhkan di masa depan.

\section{Keterbatasan Penelitian}

Peneliti menyadari bahwa pada penelitian ini terdapat banyak keterbatasan, baik secara konseptual maupun metode. Secara konseptual, peneliti sangat terbatas dalam hal referensi penelitian terdahulu mengenai hubungan atau pengaruh pemahaman guru tentang karakter siswa dan keterampilan abad ke-21 terhadap gaya mengajar guru. Secara metode, keterbatasan utama penelitian ini adalah metode one-shot yang digunakan dalam pengumpulan data, yaitu instrumen yang digunakan tidak melalui tahap uji coba terlebih dahulu. Hal ini diakibatkan keterbatasan waktu yang dimiliki peneliti. Demikian pula halnya jika ada butir pernyataan yang secara struktur kalimat kurang efektif, peneliti tidak dapat melakukan perbaikan. Keterbatasan metode lainnya adalah model kuesioner yang digunakan adalah evaluasi diri yang sifatnya sangat subjektif. Hal ini tentu dapat menjadi bias karena apabila partisipan menilai kompetensi diri berdasarkan refleksi pribadi, maka partisipan mungkin saja mengisi kuesioner dengan berpatokan pada hasil yang ideal dan kurang sesuai dengan realita. 


\section{SIMPULAN DAN SARAN}

\section{Simpulan}

Hasil penelitian menunjukkan bahwa terdapat pengaruh efikasi diri guru, pemahaman guru tentang karakter siswa generasi Z, dan pemahaman guru tentang keterampilan abad ke-21 secara simultan terhadap gaya mengajar guru tipe fasilitator di Sekolah Dian Harapan Jakarta. Ketiga variabel ini secara bersama-sama berkontribusi terhadap gaya mengajar tipe fasilitator.

Gaya mengajar tipe fasilitator merupakan gaya mengajar yang dapat menjawab kebutuhan siswa di masa kini. Guru tidak lagi menjadi sumber belajar yang terutama melainkan memfasilitasi pembelajaran siswa sehingga mereka menjadi pembelajar yang aktif dan mandiri. Agar dapat menerapkan gaya mengajar tipe fasilitator, guru perlu memiliki efikasi diri yang tinggi di dalam menjalankan perannya, serta dalam menghadapi berbagai tantangan, khususnya tantangan perkembangan teknologi yang juga turut masuk ke dalam dunia pendidikan. Selain itu, guru juga perlu memiliki pemahaman yang baik tentang karakteristik siswa, terutama dalam hal cara belajar, serta memahami keterampilan-keterampilan apa yang mereka butuhkan di masa depan untuk dapat menjawab tantangan zaman. Dengan pemahaman yang baik terhadap kedua aspek ini, maka peran guru sebagai fasilitator di dalam merancang dan melaksanakan kegiatan belajar siswa dapat menjadi lebih optimal.

\section{Saran Teoretis}

Berdasarkan hasil keterbatasan dan penelitian, terdapat beberapa saran untuk penelitian selanjutnya. Pertama, variabel pemahaman guru tentang karakter siswa generasi Z memberikan kontribusi terbesar bagi gaya mengajar tipe fasilitator. Penelitian selanjutnya disarankan dapat mengeksplorasi lebih banyak lagi dimensi pada variabel ini, yaitu gaya belajar dan hubungan sosial. Kedua, variabel pemahaman guru tentang keterampilan abad ke-21 juga memberikan kontribusi yang besar bagi gaya mengajar fasilitator. Oleh karena itu, perlu dikembangkan kajian bagaimana memfasilitasi pembelajaran abad ke-21 yang efektif dan dikaitkan dengan perkembangan teknologi yang erat dengan kehidupan siswa masa kini. Terakhir, penelitian selanjutnya dapat menambahkan variabel prediktor mengingat sumbangan atau kontribusi ketiga variabel prediktor dalam penelitian ini masih dapat ditingkatkan lagi. 


\section{Saran Praktis}

Penting sekali bagi setiap guru memiliki efikasi diri yang tinggi dalam menjalankan tugastugasnya karena guru adalah sosok teladan bagi siswa dalam belajar dan berperilaku sehari-hari. Kemudian, guru juga perlu mengerti bagaimana karakteristik siswa-siswanya, terutama dalam hal belajar dan berhubungan dengan lingkungan sekitarnya. Pengenalan yang baik terhadap karakter siswa akan menolong guru memahami kebutuhan siswa dan bagaimana cara mereka belajar, sehingga tujuan pembelajaran dapat tercapai. Selain itu, guru perlu membantu siswa mengembangkan keterampilan-keterampilan yang dibutuhkan dalam menjawab tantangan abad ke21. Bagi pimpinan sekolah, disarankan untuk memperhatikan pengembangan desain pembelajaran yang harus mempertimbangkan karakteristik siswa dan tuntutan zaman dalam rangka mempersiapkan siswa menghadapi tantangan di masa depan, serta pelatihan-pelatihan dalam rangka meningkatkan kompetensi guru, baik dalam hal pedagogi maupun profesional.

\section{REFERENSI}

Ahmadi, A., \& Prasetya, J. (2005). Strategi belajar mengajar. Bandung: Pustaka Setia.

Alwisol. (2018). Psikologi kepribadian. Malang: Universitas Muhammadiyah Malang.

Bala, R. (2018). Menjadi guru hebat zaman now. Jakarta: Grasindo.

Bencsik, A., Csikos, G., \& Juhaz, T. (2016). Y and Z Generations at Workplaces. Journal of Competitiveness, 8(3), 90-106. doi: 10.7441/joc.2016.03.06

Balachandran, T. (2015). Why teachers teach the way they do: Factors influencing the perceptual teaching styles of teacher candidates in math education (Tesis tidak dipublikasikan). University Toronto, Toronto.

Baleghizadeh, S., \& Shakouri, M. (2017). Investigating the relationship between teaching styles and teachers self-efficacy among some Iranian ESP University Instructor. Innovations in Education and Teaching International, 54(4), 394-402. doi: 10.1080/14703297.2015.1087329

Bandura, A. (1997). Self efficacy: The exercise of control. New York, NY: W.H. Freeman \& Company.

Beyhan, O. (2018). Student perceptions on the teaching styles of their teachers. Journal of Education, 33(4), 1038-1048. doi: 10.16986/HUJE.2018036946 
Bosscher, R. J., \& Smit, J. H. (1998). Confirmatory factor analysis of the general self-efficacy scale. Behaviour Research and Theraphy, 36(3), 339-343. doi: 10.1016/S00057967(98)00025-4

Carter, T. (2018). Preparing generation $\mathrm{Z}$ for the teaching profession. SRATE Journal Winter, 27(1), $1-8$.

Chun, C., Dudoit, K., Fujihara, S., Gerschenson, M., Kennedy, A., Koanui, B., Ogata, V., \& Stearns, J. (2017). Teaching generation $Z$ at the University of Hawai' $i$. Paper presented at the IAFOR International Conference on Education - Hawaii 2017. Ditemu kembali dari https://papers.iafor.org/submission34202/

Grasha, A. (2002). Teaching with style: A practical guide to enhancing learning by understanding teaching and learning style. California: Alliance Publishers.

Jan, H. (2017). Teacher of 21st century: Characteristics and development. Research of Humanities and Social Science, 7(29), 49-54.

Kereluik, K., Mishra, P., Fahnoe, C., \& Terry, L. (2013). What knowledge is of most worth: Teacher knowledge for 21st century learning. Journal of Digital Learning in Teacher Education, 29(4), 127-140.

Mishra, P., \& Mehta, R. (2016). What we educators get wrong about 21st century learning: Results of a survey. Journal of Digital Learning in Teacher Education, 33(1), 6-19. doi: $10.1080 / 21532974.2016 .1242392$

Mulayasa, E. (2013). Standar kompetensi dan sertifikasi guru. Bandung: PT Remaja Rosdakarya.

Nai, F. (2017). Teori belajar dan pembelajaran: Implementasinya dalam pembelajaran bahasa Indonesia di SMP, SMA, dan SMK. Yogyakarta: Deepublish.

Nouri, J. (2016). The flipped classroom: For active, effective and increased learning - especially for low achievers. International Journal of Educational Technology in Higher Education, 13(33), 1-10. doi: 10.1186/s41239-016-0032-z

Pemerintah Indonesia. (2005). Undang-Undang Republik Indonesia Nomor 14 Tahun 2005 tentang guru dan dosen. Jakarta: Sekretariat Negara.

Pratama, H. (2012). Cyber parenting. Bandung: PT Visi Anugerah Indonesia.

Rahmawati, M., \& Suryadi, E. (2019). Guru sebagai fasilitator dan efektivitas belajar siswa. Jurnal Pendidikan Manajemen Perkantoran, 4(1), 49-54.

Ramar, H., \& Sharma, G. (2016). Personal and professional attitudes of generation Z students' talent management. International Journal of Circuit Theory and Application, 9(37), 471-478. 
Ravitz, J. (2014). A survey for measuring 21st Century skills teaching and learning: West Virginia 21st Century teaching and learning survey. Evaluation and Research Professional. doi: 10.13140/RG.2.1.2246.6647

Saswandi, T. (2014). Teaching style and students' interest in learning English. Jurnal Penelitian Universitas Jambi Seri Humaniora, 17(1).

Schwieger, D., \& Ludwig, C. (2018). Reaching and retaining the next generation: Adapting to the expectations of gen $\mathrm{Z}$ in the classroom. Information Systems Education Journal, 16(3), 4554.

Suganda, T. (2018). Pengelolaan pembelajaran generasi Z. Paper dipresentasikan pada Seminar Pembelajaran bagi Generasi $Z$ di Stipar Yapari, Bandung, Indonesia. doi: 10.13140/RG2.2.23700.60800

Sural, S. (2019). The investigation of primary and secondary teachers' in-class approach in terms of teaching styles and comparing it with their classroom management approach. Journal Turkish Studies, 14(1), 651-666. doi: 10.7827/TurkishStudies.14825

Tschannen-Moran, M., \& Hoy, A. (2019). Teacher efficacy: Capturing an elusive construct. Teaching and Teacher Education, 17, 783-805. doi: 10.1016/S0742-051X(01)00036-1

Wicoro, T. (2018). Hubungan antara efikasi diri guru dan motivasi mengajar guru sekolah dasar (Skripsi tidak dipublikasikan). Universitas Islam Indonesia, Indonesia. 